\title{
MORPHOLOGICAL AND MOLECULAR CHARACTERIZATION OF Pisolithus IN SOIL UNDER EUCALYPTUS PLANTATIONS IN BRAZIL ${ }^{(1)}$
}

\author{
Maria Catarina Megumi Kasuya ${ }^{(2)}$, Irene da Silva Coelho( ${ }^{(3)}$, Daniela Tiago da \\ Silva Campos ${ }^{(4)}$, Elza Fernandes de Araújo ${ }^{(2)}$, Yutaka Tamai ${ }^{(5)}$ \& Toshizumi
}

Miyamoto $^{(5)}$

\section{SUMMARY}

Eighteen Pisolithus basidiomes were collected from Eucalyptus plantations in the state of Minas Gerais, Brazil. These basidiomes were characterized morphologically and molecularly. The basidiomes varied in shape, color and size. One of them was found underground, indicating a hypogeous fungus. The main morphological distinctive characteristic was spore ornamentation, which distinguished two groups. One group with short and erect spines was identified as Pisolithus microcarpus, and the other with long and curved spines as Pisolithus marmoratus, after analyzing the cladogram obtained by phylogenetic relationship based on internal transcribed spacer (ITS) regions of the nuclear ribosomal DNA of these isolates.

Index terms: ectomycorrhizal fungus, phylogenetic analysis; internal transcribed spacer (ITS), nuclear ribosomal DNA, taxonomy.

\footnotetext{
(1) Part of Pos-doctorate, Agricultural Microbiology, Federal University of Viçosa, Brazil. Received for publication in November, 2009 and approved in October 2010.

${ }^{(2)}$ Professor, Microbiology Department, Federal University of Viçosa, Brazil. E-mails: mkasuya@ufv.br; ezfa@ufv.br

${ }^{(3)}$ Pos-doctorate student, Microbiology Department, Federal University of Viçosa, Brazil. E-mail: irenecs@yahoo.com

${ }^{(4)}$ Professor, Agricultural Microbiology, Department, Federal University of Mato Grosso, Brazil. E-mail: camposdts@yahoo.com.br

${ }^{(5)}$ Professor, Division of Environmental Resources, Hokkaido University, Japan. E-mails: ytamai@for.agr.hokudai.ac.jp; tmiyamot@for.agr.hokudai.ac.jp
} 


\title{
RESUMO: CARACTERIZAÇÃOMORFOLÓGICA E MOLECULAR DE Pisolithus OCORRENDO EM PLANTAÇÕES COMERCIAIS DE EUCALIPTOS NO BRASIL
}

\begin{abstract}
Dezoito basidiocarpos de Pisolithus foram coletados em plantações comerciais de Eucalyptus no Estado de Minas Gerais, no Brasil. Esses basidiocarpos foram caracterizados morfológica e molecularmente. Eles variaram na forma, cor e tamanho. Além disso, um deles foi encontrado abaixo do solo, sugerindo que seja um hipógeo. A principal característica morfológica distintiva foi a ornamentação dos esporos, que foram separados em dois grupos: um apresentou espiculas curtas e eretas, e o outro, espículas longas e curvas. Eles foram identificados, respectivamente, como Pisolithus microcarpus $e$ Pisolithus marmoratus, depois da análise do cladograma obtido pela relação filogenética baseada no espaçador interno transcrito (ITS) do DNA ribossomal nuclear desses isolados.
\end{abstract}

Termos de indexação: fungos ectomicorrízicos, análise filogenética, espaçador interno transcrito (ITS), DNA ribossomal nuclear, taxonomia.

\section{INTRODUCTION}

Pisolithus is a group of gasteromycetes with worldwide distribution that form ectomycorrhizas with a wide range of angiosperm and gymnosperm tree species (Marx, 1977).

The dispersal of ectomycorrhizal trees, such as eucalyptus and pine, outside their natural range, has resulted in the introduction of a narrow range of exotic ectomycorrhizal fungi into forest plantations in many countries of Europe, South America, Africa and Asia (Garbaye et al., 1988; Martin et al., 1998; Gomes et al., 2000; Díez et al., 2001; Singla et al., 2004; Reddy et al., 2005). Whether the distribution of these fungi reaches beyond these areas depends on the host range of the fungi and their ability to compete with indigenous species.

Since Pisolithus was described, several taxa have been proposed based on distinctive carpophore and basidiospore morphology (Marx, 1977). There is considerable polymorphism in terms of basidiomes, spore and culture morphology in Pisolithus strains (Burgess et al., 1995; Watling et al., 1995; Anderson et al., 1998; Kasuya et al., 2008). Large variations in colony growth rates, enzyme activity, polypeptide patterns, and mycorrhizal ability have been reported (Kope \& Fortin, 1990; Lamhamedi et al., 1990; Burgess et al., 1994, 1995. Based on basidiospore morphology and mating incompatibility tests, Kope \& Fortin (1990) proposed that the genus Pisolithus comprises several biological species.

DNA-based methods have provided further support for this hypothesis. Junghans et al. (1998) reported that RAPD analysis (Random Amplification of Polymorphic DNA) clustered Pisolithus isolates in two main groups, according to host and geographical origin. Using the same isolates, these data were confirmed by Restriction Fragment Length
Polymorphism (RFLP) in the internal transcribed spacer (ITS) regions amplified by Polymerase Chain Reaction (PCR) and on mitochondrial DNA (Gomes et al., 1999, 2000). Based on RFLP analysis of the ITS sequences of several Pisolithus isolates, Farmer \& Sylvia (1998) suggested that this taxon represents a complex species. At least 11 different clades have been reported, of which the major were recognized as phylogenetic species (Martin et al., 2002).

Studies based on DNA sequences serve to reevaluate earlier classifications and delimit species more accurately (Taylor et al., 2000). The progress of phylogeny studies and their implications for understanding the biogeography of ectomycorrhizal fungi has been significant (Jarosh \& Bresinsky, 1999; Wu et al., 2000; Kanchanaprayudh et al., 2003; Moyersoen et al., 2003; Singla et al., 2004).

Although inoculation is not a rule in tree nurseries in Brazil, it is rather common to find Pisolithus basidiomes under commercial eucalyptus plantations. However, with exception of the Southern region, where P. microcarpus was found (Giachini et al., 2000), Pisolithus basidiomes in other areas have not been identified at the species level. The objective of this study was to identify the Pisolithus species found in eucalyptus plantations in the state of Minas Gerais.

\section{MATERIAL AND METHODS}

\section{Sampling and sites}

Basidiomes of 18 Pisolithus isolates, collected from the soil of commercial plantations of Eucalyptus spp., between February/2002 and February/2004, in different areas of CENIBRA - Celulose Nipo-Brasileira S.A., in Minas Gerais, Brazil, were used in this study. 


\section{Electron microscopic observation of basidio- spores}

Basidiospores from mature basidiomes were airdried and sputter-coated with gold+palladium before examination under a JSM5310 scanning electron microscope, low vacuum, at an accelerating voltage of $15 \mathrm{kV}$. Mean basidiospore diameter $(\mathrm{n}=20)$ was determined for each isolate using scanning electron micrographs and basidiospore spine morphology classified by the terminology of Kope \& Fortin (1990).

\section{DNA manipulations}

Samples of Pisolithus spores or internal parts of dried mushrooms were used for DNA extraction. DNA was isolated using DNAeasy Kit (Qiagen, Düsseldorf, Germany). The ITS region of rDNA (ITS1-5.8S-ITS2) was amplified with ITS1f (Gardes \& Bruns, 1993) and ITS4 primers (White et al., 1990). Amplifications were performed on a GeneAmp PCR System 2400 (Perkin-Elmer). Samples were initially denatured for $30 \mathrm{~s}$ at $94^{\circ} \mathrm{C}$, followed by 40 cycles of denaturation for $1 \mathrm{~min}$ at $94^{\circ} \mathrm{C}$, annealing for $1 \mathrm{~min}$ at $55^{\circ} \mathrm{C}$, and extension for $2 \mathrm{~min}$ at $72{ }^{\circ} \mathrm{C}$.

Samples of PCR products were purified using QIAquick ${ }^{\circledR}$ PCR purification kit (Qiagen, Düsseldorf, Germany) and sequenced by the ByeDyeTM Terminator Cycle Sequencing Ready Reaction kit (Applied Biosystems, USA), according to the manufacturer's instructions. Sequences were generated for both strands using the ITS1f and ITS4 primers for comparison and to ensure reliability.

\section{Sequence analysis}

The sequences were deposited in a GenBank database (Table 1), and compared with other sequences (Table 2). The sequences were imported into MEGA, version 3.1 (Kumar et al., 2004), and aligned using the program Clustal W (Higgins et al., 1994). The resulting multiple alignments were optimized visually. The final alignment of this study is available on request. ITS sequences of Paxillus involutus (AF167700) and Suillus luteus (L54110) were used as outgroup taxa. A neighbor joining (NJ) algorithm method was used for phylogenetic analysis, applying a p-distance model with software MEGA (Kumar et al., 2004). The robustness of each branch was determined using the nonparametric bootstrap test (Felsenstein, 1985) with 1000 replicates.

\section{RESULTS}

The basidiomes shape and size varied (Table 1). Furthermore, isolate VIC 30600 was found underground, indicating a hypogeous fungus. Two distinctive spore ornamentations were observed, forming one group with the isolates VIC 30596, VIC 30597 and VIC 30600, with long and curved spines, and spore diameter from 7.24 to $7.91 \mu \mathrm{m}$ (Figure 1, Table 1). The other isolates had short and erect spines and a spore diameter from 6.2 to $8.62 \mu \mathrm{m}$ (Figure 1, Table 1). As many as eight basidiospores per basidium were observed in all cases (data not shown).

Table 1. Isolate identification, spore diameter including spines, basidiome size, growth habit, and GenBank accession of Brazilian Pisolithus isolates used in this study

\begin{tabular}{|c|c|c|c|c|}
\hline Isolates & Spores diameter & $\begin{array}{l}\text { Basidiome size width } \times \text { height } \\
\text { (stipe height) }\end{array}$ & Growth habit & GenBank accession \\
\hline & $\mu \mathrm{m}$ & $\mathrm{mm}$ & & \\
\hline VIC 30590 & Immature & $36 \times 43(20)$ & Epigeous & - \\
\hline VIC 30591 & Immature & $17 \times 26(10)$ & Epigeous & - \\
\hline VIC 30592 & $7.12 \pm 0.60$ & $48 \times 42(18)$ & Epigeous & - \\
\hline VIC 30593 & Immature & $33 \times 30(00)$ & Epigeous & HQ693094 \\
\hline VIC 30594 & $6.40 \pm 0.54$ & $28 \times 60(28)$ & Epigeous & - \\
\hline VIC 30595 & Immature & $28 \times 38(16)$ & Epigeous & - \\
\hline VIC 30596 & $7.91 \pm 0.96$ & $57 \times 28(05)$ & Epigeous & HQ693095 \\
\hline VIC 30597 & Immature & $28 \times 28(00)$ & Epigeous & HQ693096 \\
\hline VIC 30598 & $7.09 \pm 0.76$ & $25 \times 29(05)$ & Epigeous & HQ693097 \\
\hline VIC 30599 & Immature & $18 \times 37(00)$ & Epigeous & HQ693098 \\
\hline VIC 30600 & $7.24 \pm 0.7$ & $24 \times 15(00)$ & Hypogenous & HQ693099 \\
\hline VIC 30601 & Immature & $52 \times 50(27)$ & Epigeous & - \\
\hline VIC 30602 & Immature & $36 \times 30(10)$ & Epigeous & HQ693100 \\
\hline VIC 30603 & Immature & $28 \times 34(08)$ & Epigeous & - \\
\hline VIC 30604 & $8.62 \pm 0.65$ & $46 \times 58(34)$ & Epigeous & HQ693101 \\
\hline VIC 30605 & $6.20 \pm 0.50$ & $52 \times 55(08)$ & Epigeous & - \\
\hline VIC 30606 & $7.24 \pm 0.51$ & $62 \times 86(22)$ & Epigeous & HQ693102 \\
\hline VIC 30607 & $6.82 \pm 0.52$ & $75 \times 96(45)$ & Epigeous & - \\
\hline
\end{tabular}


Table 2. Pisolithus isolates with information concerning host, geographical origin and GenBank accession number

\begin{tabular}{|c|c|c|c|}
\hline Isolate & Host plants & Locality & GenBank accession \\
\hline PT90A & Eucalyptus sp. & Viçosa, Brazil & $\mathrm{AF} 140547^{(1)}$ \\
\hline $\mathrm{RS} 26$ & Eucalyptus sp. & Viçosa, Brazil & $\mathrm{AF} 142991^{(3)}$ \\
\hline MU98/5A & E. globules & Kudardup, Western Australia & AF374644 ${ }^{(3)}$ \\
\hline MU98/9 & E. globules & Scott R, Western Australia & AF374649 ${ }^{(3)}$ \\
\hline MU98/2 & E. marginata & Augusta, Western Australia & AF374641 ${ }^{(3)}$ \\
\hline MU98/12 & Eucalyptus sp. & Manjimup, Western Australia & AF374652 (3) \\
\hline MARX270 & P. elliottii & Georgia, USA & AF37 $4632^{(3)}$ \\
\hline РT301 & Pinus sp. & Georgia, USA & $\mathrm{AF} 143233^{(1)}$ \\
\hline Pasoh01 clone 1 & Shorea macroptera & Forest Service, Pasoh, Malaysia & AF415226 ${ }^{(3)}$ \\
\hline MURU5134 & & Western Australia & AY $179746^{(4)}$ \\
\hline PTJap (MH175) & P. pumila/Betula ermaniii & $\begin{array}{l}\text { Mt Iou, Shiretoko Peninsula, Hokkaido, } \\
\text { Japan }\end{array}$ & AF37 $4629^{(3)}$ \\
\hline FORBs05006 & $\begin{array}{l}\text { B. maximowicziana, B. platyphila, } \\
\text { Abies sachalinensis, Larix. Leptolepis }\end{array}$ & Rankoshi & $\mathrm{EF} 192104^{(2)}$ \\
\hline FORBs05010 & P. pumila, B. ermanii & AkaAkan & $\mathrm{EF} 192107^{(2)}$ \\
\hline
\end{tabular}

${ }^{(1)}$ Gomes et al. (2000). ${ }^{(2)}$ Kasuya et al. (2008). ${ }^{(3)}$ Martin et al. (2002). ${ }^{(4)}$ Thomas et al. (2003).

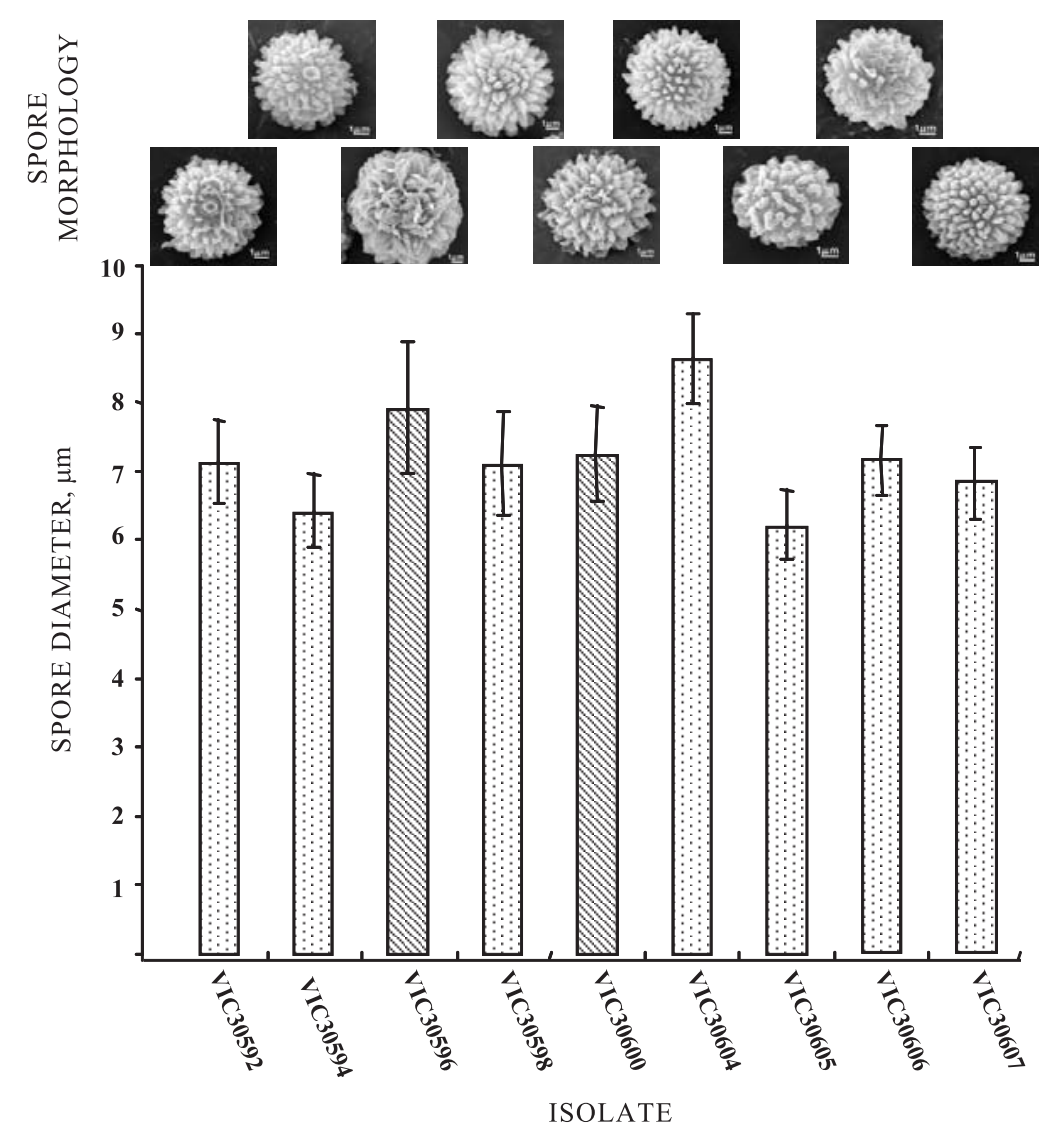

Figure 1. Morphology and spore diameter $(\mathrm{n}=20)$ of Brazilian Pisolithus isolates.

PCR amplification with the specific primers for the ITS region generated only band with $700 \mathrm{bp}$. In the phylogenetic analysis, all sequences in the cladogram were divided into three major clades. The structures were similar to the phylogenetic cladogram in Martin et al. (2002). The sequences of all isolates 
used in this study were distributed in clades 1 and 2 , with strong bootstrap support (99 \%) (Figure 2).

Clade 1 consisted of four species groups. The first species included isolates VIC 30596, VIC 30597 and VIC 30600 that grouped with MU98/5A and MU98/9, identified as Pisolithus marmoratus, isolated from Eucalyptus globulus in a forest of Australia (Martin et al., 2002). The second species group was the hypogeneous Pisolithus called $P$. hypogaeus. The isolates MARX270 and PT301 formed a species group identified as Pisolithus tinctorius, both from the United States and isolates from Pinus forests. The last species group contained other species, all from Japan (Figure 2, Table 2).

The isolates were separated into two monophyletic groups with strong bootstrap support (100 \%) in clade 2. One group included the isolates VIC 30593,
VIC 30598, VIC 30599, VIC 30602, VIC 30604, and VIC 30606, together with PT90A and RS26, also from Brazil (Figure 2, Tables 1 and 2), and was identified as Pisolithus microcarpus (Martin et al., 2002). The other group that included MU98/2 and MU98/12, was identified as Pisolithus albus, native to Australia (Martin et al., 2002) (Table 2, Figure 2).

\section{DISCUSSION}

The characteristic that distinguished the two species found in the studied area was spore ornamentation (Figure 1), as confirmed by molecular analysis (Figure 2). One group with short and erect spines was identified as Pisolithus microcarpus, and

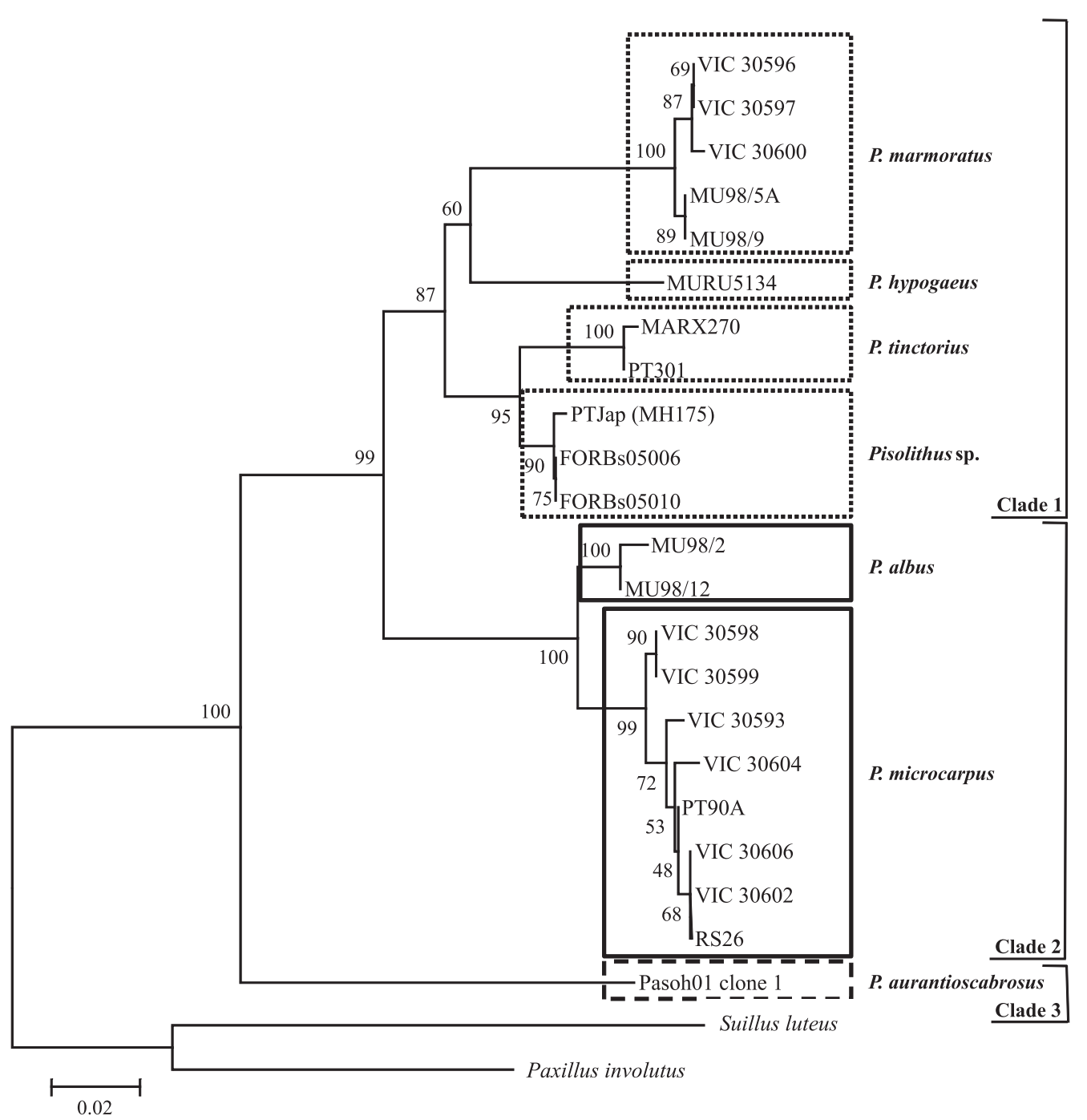

Figure 2. Cladogram obtained by phylogenetic relationships in Pisolithus based on the rDNA ITS sequence. The tree was rooted using Paxillus involutus and Suillus luteus as outgroups. Numbers in the branches indicate the bootstrap support based on 1000 replicates (if $>50 \%$ ). The species were named as proposed by Martin et al. (2002). 
the other with longer and curved spines as Pisolithus marmoratus.

Pisolithus microcarpus and P. marmoratus were described by Bougher \& Syme (1998). Although native to Australia, isolates of this species were collected in exotic plantations worldwide (e.g. Brazil, China, Portugal, Senegal, and South Africa). P. marmoratus is considered the southern hemisphere counterpart of $P$. tinctorius. They are morphologically very similar (Bougher \& Syme, 1998), but unlike $P$. tinctorius, P. marmoratus is associated with eucalypts.

The clustering of all Pinus isolates together is consistent, from the point of view that some degree of host specificity may exist within the Pisolithus taxa (Martin et al., 1998). Several previous studies have suggested that Pisolithus isolated from basidiomes occurring under Pinus spp. are poor colonizers of Eucalyptus spp. (Burgess et al., 1994; Junghans et al., 1998; Pereira et al., 2005). Moreover, in a molecular study of Pisolithus in Kenya, three taxa were identified as occurring only in either pine plantations, eucalyptus plantations or native Afzelia vegetation (Martin et al., 1998).

Basidiome morphology has been used in Pisolithus taxonomy (Watling et al., 1995; Kanchanaprayudh et al., 2003; Thomas et al., 2003), but size and shape were not useful due to the possible influence of soil and environmental conditions and could not identify Pisolithus in Hokkaido (Kasuya et al., 2008). Although isolate VIC 30600 was found to be hypogaeous (Table 1), it was not included in the P. hypogaeus species, described occurring in Australia (Thomas et al., 2003). Instead, the isolate VIC 30600 presents similarity with the $P$. microcarpus spores and this date was confirmed by phylogenetic analysis.

Genetic diversity and host specificity of Pisolithus was reported in exotic Eucalyptus and native hosts in the western Mediterranean region. The ITS sequences suggested the occurrence of several ecological species adapted to exploit different soil types (basic, acid and clayey slate-derived soils), with specificity for particular indigenous hosts. Isolates from eucalypt plantations in Brazil, Kenya and the Mediterranean region grouped together with eucalypt-associated Australian isolates. No transfer to native hosts occurred; the host specificity range of these exotic strains may prevent out-competition and interbreeding with local species. The origin of Pisolithus spp. in eucalypt plantations in the Mediterranean basin is Australia; the co-introduction of the ectomycorrhizal fungi might explain the success of these exotic forest plantations (Díez et al., 2001).

In Thailand, the presence of at least three Pisolithus species was suggested. Pisolithus basidiomes collected in pine forests and under some Shorea roxburghii trees in a pine-dipterocarp forest corresponded to species 5 , as previously described by
Martin and collaborators in 2002. The basidiomes collected under S. roxburghii and Dipterocarp alatus trees in the dipterocarp forests did not match any previously reported species. Basidiomes collected from eucalyptus plantations were all identified as Pisolithus albus (Kanchanaprayudh et al., 2003).

Australian eucalypts was introduced into Southeast Asia, India, Africa, South America, South Africa, and southern Europe in the last 200 year in form of seeds and saplings, which facilitated the dispersal of Australian Pisolithus (Martin et al., 2002).

The ITS sequences of rDNA of Pisolithus isolates were also determined to provide information on the genetic variability among isolates and to compare the sequences to other isolates described in the literature. This study should provide a better understanding of the taxonomy and variability of Pisolithus in Brazil, underlying the selection of fungal genotypes for forestry inoculation programs. Such programs are of key importance, since forest management is an essential part of Brazilian agriculture.

\section{CONCLUSIONS}

1. The trait spore ornamentation is a criterion to distinguish the Pisolithus species.

2. Molecular analysis confirmed the presence of two Pisolithus species in the State of Minas Gerais.

3. The two Pisolithus species in the study area were Pisolithus microcarpus and Pisolithus marmoratus.

\section{ACKNOWLEDGEMENTS}

We thank the CNPq, Capes and FAPEMIG (Brazilian Institutions for Research Support) and the Ministry of Education, Culture, Sports, Science and Technology of Japan (Grant-in-Aid - 16208032) for financial support.

\section{LITERATURE CITED}

ANDERSON, I.C.; CHAMBERS, S.M. \& CAIRNEY, J.W.G. Molecular determination of genetic variation in Pisolithus isolates from a defined region in New South Wales, Australia. New Phytol., 138:151-162, 1998.

BOUGHER, N.L. \& SYME, K. Fungi of Southeastern Australia. Perth, University of Western Australia Press, 1998. 391p.

BURGESS, T.; DELL, B. \& MALAJCZUK, N. Variation in mycorrhizal development and growth stimulation by 20 Pisolithus isolates inoculated onto Eucalyptus grandis W. Hill ex Maiden. New Phytol., 127:731-739, 1994. 
BURGESS, T.; MALAJCZUK, N. \& DELL, B. Variation in Pisolithus based on basidiome and basidiospore morphology, culture characteristic and analysis of polypeptide using 1D SDS-PAGE. Mycol. Res., 99:1-13, 1995.

DÍEZ, J.; ANTA, B.; MANJÓN, J.L. \& HORUMBIA, M. Genetic variability of Pisolithus isolates associated with native hosts and exotic Eucalyptus in the Western Mediterranean region. New Phytol., 149:577-587, 2001.

FARMER, D.J. \& SYLVIA, D.M. Variation in the ribosomal DNA internal transcribed spacer of a diverse collection of ectomycorrhizal fungi. Mycol. Res., 102:859-865, 1998.

FELSENSTEIN, J. Confidence limits on phylogenies: An approach using the bootstrap. Evolution, 39:783-791, 1985.

GARBAYE, J.; DELWAULLE, J.C. \& DIANGANA, D. Growth response of eucalyptus in the Congo to ectomycorrhizal inoculation. For. Ecol. Manag., 24:151-157, 1988.

GARDES, M. \& BRUNS, T.D. ITS primers with enhanced specificity for basidiomycetes: Application to the identification of mycorrhiza and rusts. Molec. Ecol., 2:113118, 1993.

GIACHINI, A.J.; OLIVEIRA, V.L.; CASTELLANO, M.A. \& TRAPPE, J.M. Ectomycorrhizal fungi in Eucalyptus and Pinus plantations in Southern Brazil. Mycologia, 92:11661177,2000

GOMES, E.A.; ABREU, L.M.; BORGES, A.C. \& ARAUJO, E.F. ITS sequences and mitochondrial DNA polymorphism in Pisolithus isolates. Mycol. Res., 104:911-918, 2000.

GOMES, E.A.; DE BARROS, E.G.; KASUYA, M.C.M. \& ARAUJO, E.F. Molecular characterization of Pisolithus spp. isolates by rDNA PCR-RFLP. Mycorrhiza, 8:197-202, 1999.

HIGGINS, D.; THOMPSON, J.; GIBSON, T.; THOMPSON, J.D.; HIGGINS, D.G. \& GIBSON, T.J. CLUSTAL W: Improving the sensitivity of progressive multiple sequence alignment through sequence weighting, position-specific gap penalties and weight matrix choice. Nucleic Acids Res., 22:4673-4680, 1994

HO, I. Comparison of eight Pisolithus tinctorius isolates for growth rate, enzyme activity, and phytohormone production. Can. J. For. Res., 17:31-35, 1987.

JAROSH, M. \& BRESINSKY, A. Speciation and phylogenetic distance within Paxillus s. str. (Basidiomycetes, Boletales). Plant Biol., 1:701-706, 1999.

JUNGHANS, D.T.; GOMES, E.A.; GUIMARAEA, W.V.; BARROS, E.G. \& ARAUJO, E.F. Genetic diversity of the ectomycorrhizal fungus Pisolithus tinctorius based on RAPD-PCR analysis. Mycorrhiza, 7:243-248, 1998.

KANCHANAPRAYUDH, J.; ZHOU, Z.; YOMYART, S.; SIHANONTH, P. \& HOGETSU, T. Molecular phylogeny of ectomycorrhizal Pisolithus fungi associated with pine, dipterocarp, and Eucalyptus trees in Thailand. Mycoscience, 44:287-294, 2003.
KASUYA, M.C.M.; COELHO, I.S.; TAMAI, Y.; MIYAMOTO, T. \& YAJIMA, T. Morphological and molecular characterization of Pisolithus occurring in Hokkaido Island, Northern Japan. Mycotaxon, 49:334-338, 2007.

KOPE, H.H. \& FORTIN, J.A. Germination and comparative morphology of basidiospores of Pisolithus arhizus. Mycologia, 82:350-357, 1990.

KUMAR, S.; TAMURA, K. \& NEI, M. MEGA3: Integrated software for molecular evolutionary genetics analysis and sequence alignment. Brief Bioinform., 5:150-163, 2004.

LAMHAMEDI, M.S.; FORTIN, J.A.; KOPE, H.H. \& KROPP, B.R. Genetic variation in ectomycorrhiza formation by Pisolithus arhizus on Pinus pinaster and Pinus banksiana. New Phytol., 115:689-697, 1990.

MARTin, F.; DELARUELle, C. \& IVORY, M. Genetic variability in intergenic spacers of ribosomal DNA in Pisolithus isolates associated with pine, eucalyptus and Afzelia in lowland Kenyan forests. New Phytol., 139:341352,1998

MARTIN, F.; DÍEZ, J.; DELL, B. \& DELARUELLE, C. Phylogeography of the ectomycorrhizal Pisolithus species as inferred from nuclear ribosomal DNA ITS sequences. New Phytol., 153:345-357, 2002.

MARX, D.H.; BRYAN, W.C. \& CORDELL, C.E. Survival and growth of pine seedlings with Pisolithus ectomycorrhizae after two years on reforestation sites in North Carolina and Florida. For. Sci., 16:363-373, 1977.

MOYERSOEN, B.; BEEVER, R.E. \& MARTIN, F. Genetic diversity of Pisolithus in New Zealand indicates multiple long-distance dispersal from Australia. New Phytol., 160:569-579, 2003

PEREIRA, O.L.; COSTA, M.D.; BORGES, A.C.; ARAÚJO, E.F. \& KASUYA, M.C.M. Compatibility and ectomycorrhiza formation among Pisolithus isolates and Eucalyptus spp. R. Bras. Ci. Solo, 29:337-344, 2005.

SINGLA, S.; REDDY, M.S.; MARMEISE, R. "\& GAY, G. Genetic variability and taxonomic position of ectomycorrhiza; fungus Pisolithus from India. Microbiol Res., 159:203210, 2004.

TAYLOR, J.W.; JACOBSON, D.J.; KROKEN, S.; KASUGA, T.; GEISER, D.M.; HIBBETT, D.S. \& FISHER, M.C. Phylogenetic species recognition and species concepts in fungi. Fungal Genet. Biol., 31:21-32, 2000.

THOMAS, S.R.; DUNSTAN, W.A.; DELL, B.; TRAPPE, J.M. \& MALAJCZUK, N. Pisolithus hypogaeus sp. nov: A hypogeous representative of the genus Pisolithus from Western Australia. Mycotaxon, 87:405-410, 2003.

WATLING, R.; TAYLOR, A.; SEE, L.S.; SIMS, K. \& ALEXANDER, I. A rain-forest Pisolithus - its taxonomy and ecology. Nova Hedwigia, 61:417-429, 1995 
WHITE, T.J.; BRUNS, T.; LEE, S. \& TAYLOR, J. Amplification and direct sequencing of fungal ribosomal RNA genes for phylogenetics. In: INNIS, M.A.; GELFAUD, D.H.; SNINSKY, J.J. \& WHITE, T.J., eds. PCR protocols. A guide to methods and applications. San Diego, Academic Press, 1990. p.315-322.
WU, Q-X.; MUELLER, G.M.; LUTZONI, F.M.; HUANG, Y-Q. \& GUO, S-Y. Phylogenetic and biogeographical relationships of eastern Asian and eastern North America disjunct Suillus species (Fungi) as inferred from nuclear ribosomal RNA ITS sequences. Molec. Phylogenet Evol., 17:37-47, 2000. 